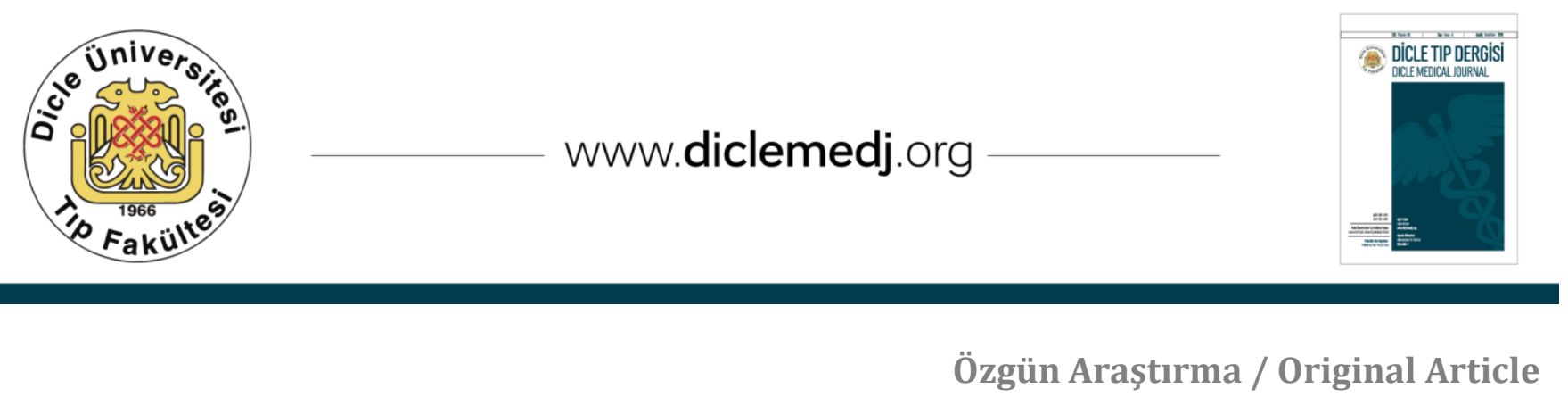

\title{
Effects of Thymoquinone on Oxidative Stress in the Testicular Tissue of Reserpinized Rats
}

\author{
Dilek Kuzay ${ }^{1}$ \\ 1 Ahi Evran University Faculty of Medicine Department of Physiology KIrşehir, Turkey ORCID: 0000-0002-1460-9883
}

Received: 23.01.2019; Revised: 02.07.2019; Accepted: 04.11.2019

\begin{abstract}
Objective: The objective of the study was to research the oxidant and antioxidant activity of Thymoquinone (TQ) in the testicular tissue of Reserpinized rats.

Methods: Eighteen rats were divided into three groups and each group had six animals: 1) Control (C) group: Received ip. 1\% Tween 80; 2) Reserpine (R) group: Received Reserpine; 3) Reserpine + TQ (R+T) group: Received Reserpine and TQ. Reserpine was injected intraperitoneally $0.2 \mathrm{mg} / \mathrm{kg}$ and TQ was administered intragastrically $10 \mathrm{mg} / \mathrm{kg}$ once daily. The rats were treated for 14 consecutive days. At the end of the study, total nitric oxide (NOx) levels, malondialdehyde (MDA) levels and glutathione (GSH) levels in the testicular tissue were examined.

Results: A statistically significant increase was observed in the NOx levels $(p=0.001)$ and MDA levels of testicular tissue in the R group $(p<0.001)$. A decrease was observed in the GSH levels $(p<0.001)$. It was found out that there was a decrease in NOx and MDA levels while there was an increase in GSH levels in the R+T group $(\mathrm{p}<0.001)$.

Conclusion: Reserpine caused an increase in oxidative stress and a decrease in antioxidant capacity in testicular tissue. TQ yielded recovery of Reserpine induced toxicity by decreasing oxidative stress markers and increasing antioxidant capacity.
\end{abstract}

Keywords: Reserpine; Oxidative stress; Rats; Testis; Thymoquinone

DOI: $10.5798 /$ dicletip

Yazışma Adresi / Correspondence: Dilek Kuzay, Department of Physiology, Faculty of Medicine, Ahi Evran University, 40100 Kırşehir, Turkey e-mail: dilekkuzay@gmail.com 


\section{Reserpinize Sıçanların Testis Dokusunda Oksidatif Stres Üzerine Thymoquinone'nin Etkisi}

\section{Öz}

Amaç: Çalışma Reserpinize sıçanların testis dokusunda Thymoquinone (TQ)' nun oksidan ve antioksidan etkinliğini araştırmak amacıyla yapıldı.

Yöntemler: 18 adet Wistar Albino sıçan her grupta 6 sıçan olacak şekilde 3 eşit gruba ayrıldı. Kontrol(K) grubu: intraperitoneal \%1 Tween 80 verildi. Reserpin(R): Reserpine verildi. Reserpine+TQ (R+T): Reserpine ve TQ verildi. Reserpin intraperitoneal $0.2 \mathrm{mg} / \mathrm{kg}$ enjekte edildi ve TQ intragastrik $10 \mathrm{mg} / \mathrm{kg}$ günde bir kere verildi. Deney ardışı $\mathrm{k}$ 14 gün sürdü. Çalışmanın sonunda testis dokusunda toplam nitrik oksit (NOx), malondilaldehit (MDA) ve glutatyon (GSH) düzeyleri bakıldı.

Bulgular: R grubunda testis dokusunun NOx düzeylerinde $(\mathrm{p}=0.001)$ ve MDA düzeylerinde istatistiksel olarak önemli bir artış oldu $(\mathrm{p}<0.001)$. GSH düzeylerinde ise azalma oldu $(\mathrm{p}<0.001)$. $\mathrm{R}+\mathrm{T}$ grubunun NOx ve MDA düzeylerinde azalma, GSH düzeylerinde ise artış olduğu belirlendi ( $\mathrm{p}<0.001)$.

Sonuç: Reserpine testis dokuda oksidatif stresi arttırdı ve antioksidan kapasiteyi azalttı. TQ tedavisi oksidatif stres markırlarını azaltıp, antioksidan kapasiteyi artırarak Reserpine ile indüklenen toksisitede iyileşme sağladı.

Anahtar kelimeler: Rezerpin, Oksidatif stres, Sıçan, Testis, Timokinon.

\section{INTRODUCTION}

Oxidative stress is a disturbance that occurs in the balance between the generation of reactive oxygen species (ROS) and antioxidant defenses. Such disturbance can damage DNA, proteins, and lipids, and eventually causes apoptosis or necrosis in living cells. There are several factors leading to oxidative stress, such as drugs, chemicals and radiation exposure through redox-catalysis and encompass reactive oxygen species (ROS), reactive nitrogen species (RNS), sulfur-centered radicals and many others 1,2 . MDA, which is the result of the lipid peroxidation, is a highly reactive three carbon dialdehyde and among the most intensively aldehydes that are formed during lipid peroxidation. RNS, a free radical such as NO and peroxynitrite (ONOO-) which is an extremely potent cellular oxidant produced with the reaction of NO with superoxide $(02 \bullet-$ ), acts together with other ROS to damage cells and thus causes nitrosative stress ${ }^{3}$. It is known that Glutathione (GSH) as a nonprotein thiol functions as an important antioxidant in the detoxification of xenobiotics, carcinogens, free radicals and the maintenance of immune functions ${ }^{4}$.

Reserpine, which is a blocker of the vesicular monoamine transporter, is known to be a powerful oxidant. It is an alkaloid which can be found in the roots of Rauwolfia serpentina and R. vomitoria. It inhibits the uptake of norepinephrine into storage vesicles and this results in the depletion of catecholamines and serotonin from central and peripheral axon terminals ${ }^{5-8}$. The catecholamines that are not stored in synaptic vesicles are exposed to degradation either by autoxidation or by oxidative deamination catalyzed by monoamine oxidase (MAO). Consequently, the increased cytoplasmic catecholamines cause not only an acceleration of catecholamines catabolism by MAO but also an elevated autoxidation of catecholamines. This leads to the overproduced reactive species that are involved in the degenerative processes and an alteration in the status of the oxidative stress of catecholamines nerve terminals ${ }^{9}$. Since reserpine is a powerful oxidant $^{10}$ and due to its other listed effects, it is used to form an experimental depression 
model and induce stress in experimental animals ${ }^{11}$.

Black cumin seed (Nigella sativa) is used in traditional medicine in many countries such as Turkey, Greece, Egypt and many others in Africa and Asia ${ }^{12}$. The main component of the Nigella sativa is Thymoquinone (TQ) ${ }^{13}$. TQ isknown to have powerful anti-inflammatory and antioxidant effects ${ }^{14,15}$. TQ exerts an antioxidant effect by causing an increase in the production of antioxidant enzymes [i.e. catalase (CAT), glutathione peroxidase (GPx), superoxide dismutase (SOD), and nitrite-nitrate (NIT)] and a decrease in lipid peroxidation ${ }^{16-17}$. TQ supplementation significantly protects many organs against oxidative damage that is caused by a variety of free radical generating agents such as aflatoxin B1 evoked hepatotoxicity, nephropathy produced by gentamicin and ethanol-induced gastric mucosal injury 14,18-19. Its high potency and low systemic toxicity render TQ an assuring alternative to conventional therapeutic drugs ${ }^{20}$.

Therefore, this study aims to research the antioxidant activity of TQ in testicular tissue of reserpinized rats.

\section{METHODS}

\section{Animals}

Adult male Wistar Albino rats (weighing $250 \pm 20 \mathrm{~g}$ ) were obtained from the laboratory animal center, Gazi University. Animals were maintained in a standard $12 \mathrm{~h}$ light/dark cycle in cages with ad libitum access to food and water. They were allowed to acclimate to the environment for 14 days. The experimental procedures were all approved by the Ethics Committee on Animal Care and Use of Gazi University (Project number G.Ü.ET-16.012). Every effort was made in order to to minimize animal suffering.

\section{Drugs and chemicals}

Reserpine, TQ (CAYMAN Chemical, USA) and Tween 80 (Biomatic, USA) were used in the present study.

\section{Experimental design}

Eighteen rats were divided into three groups, each group with six animals group: 1) Control (C) group: Received ip. \%1 Tween 80; 2) Reserpine (R) group: Received Reserpine; 3) Reserpine + TQ (R+T) group: Received Reserpine and TQ. They were treated for 14 consecutive days. Reserpine was dissolved in $\% 1$ Tween 80 and it was injected intraperitoneally $0.2 \mathrm{mg} / \mathrm{kg}$ once daily ${ }^{11} .10$ $\mathrm{mg} / \mathrm{kg}$ TQ was dissolved in tap water and administered intragastrically $30 \mathrm{~min}$ prior to each reserpine injection. The drugs were prepared freshly each day and after their preparation, they were injected using a volume of $1 \mathrm{ml} / \mathrm{kg}$. Administration was conducted from 8:00 to $10: 00$.

\section{BIOCHEMICAL ANALYSES}

\section{Tissue Preparation}

The rats were sacrificed by taking blood from their hearts under anesthesia with intramuscular (im) rompun $(5 \mathrm{mg} / \mathrm{kg})+$ ketamine (45mg / kg).

After decapitation, testes that were removed from subjects were frozen in liquid nitrogen and stored at $-80^{\circ} \mathrm{C}$ up till examination.

Determination of tissue lipid peroxide level

In order to quantify lipid peroxidation, the formation of thiobarbituric acid reactive substances was measured as described previously ${ }^{21}$. The absorbance of the samples were measured spectrophotometrically at 535 $\mathrm{nm}$. An extinction coefficient of $1.56 \cdot 1051$. $\mathrm{mol}^{-1} . \mathrm{cm}^{-1}$ was used in order to express lipid peroxide levels in terms of MDA equivalents using. Lower limit of detection of TBARS (thiobarbituric acid reactive substances) was found to be $0.03 \mu \mathrm{mol} / \mathrm{l}$. 


\section{Determination of tissue GSH levels}

The GSH levels were determined using the previously described method 21. The absorbance at $412 \mathrm{~nm}$ was measured. The extinction coefficient that was used to calculate GSH levels was $13,6001 . \mathrm{mol}^{-1} . \mathrm{cm}^{-1}$. The lower limit of detection of GSH was $0.5 \mu \mathrm{mol} / \mathrm{l}$.

Determination of tissue total nitric oxide levels

Vanadium chloride (VCl3) / Griess assay was used to obtain testis NOx levels from ELISA reader $^{22}$. The samples were measured at 540 nm using ELISA reader.

\section{Statistical Analysis}

All data are expressed as the mean \pm standard deviation (SD). Data were analyzed by using Statistical Package for Social Sciences 15.0 software program. Comparisons among groups were made using one-way analysis of variance, which was followed by post hoc Tukey tests.

\section{RESULTS}

When compared to the $\mathrm{C}$ group, an increase in NOx levels in testicular tissues of the R group was observed ( $p=0.001)$. Besides, a statistically significant increase was observed in MDA levels $(p<0.001)$. As for GSH levels, there was a decrease in the R group $(\mathrm{p}<0.001)$.

When compared to the R group, a decrease was observed in NOx and MDA levels whereas there was an increase in GSH levels in the $\mathrm{R}+\mathrm{T}$ group $(\mathrm{p}<0.001)$. The values in the $\mathrm{R}+\mathrm{T}$ group were found to be closer to those in the $C$ group ( $>0.05)$. The results are presented in Figure 1, 2 and 3.

\section{DISCUSSION}

The objective of this study is to research the antioxidant activity of TQ in testicular tissue of rats. According to the results of the study, i.p Reserpine injection for 14 days resulted in an increase in MDA and NOx levels and a decrease in GSH levels in testicular tissue. Studies in literature on the effects of Reserpine on testicular tissue support the results of this study. Cui et al. stated that a single dose of subcutaneous $5 \mathrm{mg} / \mathrm{kg}$ Reserpine injection caused an increase in MDA levels and a decrease in GSH levels in testicular tissue. Reserpine was reported to be an oxidative stress indicator ${ }^{23}$. Once-daily ip. $100 \mu \mathrm{g} / \mathrm{kg}$ Reserpine injection for 48 days led to an increase in MDA levels in plasma, kidney and liver tissue $24-25$.

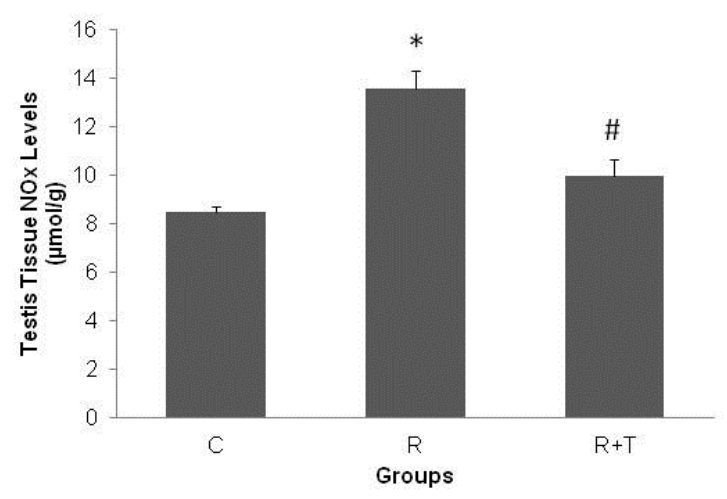

Figure 1. Testis Tissue Nox Levels ( $\mu \mathrm{mol} / \mathrm{g})$ The values are mean $\mathrm{s} \pm \mathrm{SD} ; n=6$. ${ }^{*} p<0.01$ versus $C$ groups, \# $p<0.01$ versus $R$ group

C: Control, R: Reserpine, R+T:Reserpine+TQ

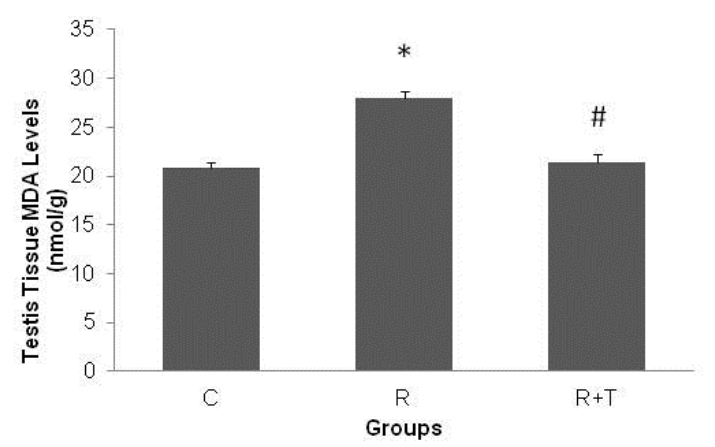

Figure 2. Testis Tissue MDA Levels ( $\mathrm{nmol} / \mathrm{g}$ ) The values are mean $\mathrm{S} \pm \mathrm{SD} ; \mathrm{n}=6$ ${ }^{*} p<0.01$ versus $C$ groups, \# $p<0.01$ versus $R$ group C: Control, R: Reserpine, R+T: Reserpine+TQ

Studies have also shown that another known effect of Reserpine is to inhibit the release of luteinizing-hormone releasing factor (LHRF) and luteinizing hormone (LH) in the hypothalamo-hypophyseal system by depleting brain stores of monoamines. $\mathrm{LH}$ is a trophic hormone necessary for the maintenance of 
interstitial tissue activity and the libido. Reserpine is known to cause impotence and decreased libido in man and this action could be due to an inhibition of LH secretion producing an atrophy or degeneration of the interstitial cells, for it is known that antibodies to LH impair libido and produce fibroblastic changes in the interstitial tissue ${ }^{26-27}$. Therefore, Reserpine was reported to have an adverse effect on the reproduction system.

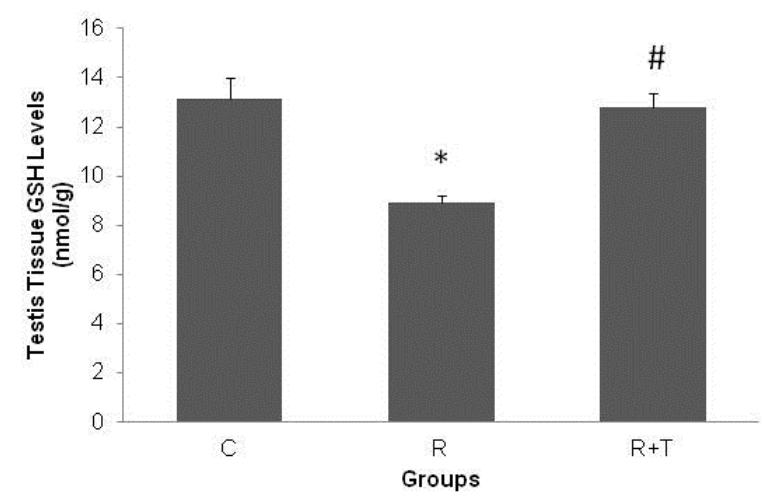

Figure 3. Testis Tissue GSH Levels ( $\mathrm{nmol} / \mathrm{g})$ The values are mean $\mathrm{SSD} ; n=6$. ${ }^{*} p<0.01$ versus $C$ groups, \# $p<0.01$ versus $R$ group

C: Control, R: Reserpine, R+T: Reserpine+TQ

The results of our study show that the effects of Reserpine on testis tissue recovered with a treatment with $10 \mathrm{mg} / \mathrm{kg}$ TQ for 14 days. MDA and NOx levels that increased in the R group decreased in the R-T group. Also, an increase in the decreased GSH levels was observed. MDA, NOx and GSH levels came closer to those of the $\mathrm{C}$ group. There are no studies in literature that research the effects of TQ on Reserpineinduced oxidative stress. The results of treatments where TQ was used against chemicals that caused toxicity in testicular tissue support the results of this study. In cadmium-induced toxicity, $10 \mathrm{mg} / \mathrm{kg}$ TQ was administered intragastrically twice a week for 56 days. GSH, superoxide dismutase (SOD) and catalase levels which decreased due to toxicity increased with TQ treatment, and lipid peroxidation (LPO) levels decreased with TQ treatment though these levels increased due to toxicity ${ }^{28}$. Mabrouk et al. reported that in rats that received $5 \mathrm{mg} / \mathrm{kg}$ TQ treatment for 5 weeks against lead $(\mathrm{Pb})$ toxicity in testicular tissue, an increase in SOD, GPX, CAT and GSH levels and a decrease in MDA levels was observed ${ }^{29}$. Khaled et al. reported that testicular damage by titanium dioxide nanoparticles (TiO2 NPs) recovered with a $20 \mathrm{mg} / \mathrm{kg}$ TQ treatment for 14 days. They reported that TQ could be a strong antioxidant ${ }^{30}$.

\section{CONCLUSION}

In the study, Reserpine injection for 14 days increased oxidative stress whereas it decreased antioxidant capacity in testicular tissue. TQ treatment yielded recovery by decreasing the oxidative stress induced with Reserpine and increasing the decreased antioxidant capacity.

\section{LIMITATIONS}

In the study, an examination of the effects of Reserpine and TQ on the direct testis functions such as lipido, sperm count, sperm structure etc. could not be made. However, oxidant and antioxidant parameters evaluated in the tissue give indirect information on the effects of Reserpine and TQ on reproduction system.

\section{ETHICAL STATEMENT}

All procedures in this study were performed in accordance with the Gazi University Laboratory Animals and Experimental Researches Center. All experimental procedures were approved by the Gazi University Ethical and Research Committee (Approval No: G.Ü.ET-16.012).

\section{ACKNOWLEDGMENTS}

This work was supported by the Ahi Evran University Scientific Research Projects Coordination Unit. Project Number: TIP.A3.17.001.

Declaration of Conflicting Interests: The authors hereby declare that no conflict of interest is in question.

Financial Disclosure: No financial support was received for the study. 


\section{REFERENCES}

1. Erdemir F, Atilgan D, Firat F, et al. The effect of Sertraline, Paroxetine, Fluoxetine and Escitalopram on testicular tissue and oxidative stres parameters in rats. Int Braz J Urol. 2014; 40: 100-8.

2. Abuja PM, Albertini R. Methods for monitoring oxidative stress, lipid peroxidation and oxidation resistance of lipoproteins. Clin Chim Acta. 2001; 306: 117.

3. Squadrito GL, Pryor WA. Oxidative chemistry of nitric oxide: the roles of superoxide, peroxynitrite, and carbon dioxide. Free Radic. Biol. Med. 1998; 25: 392403.

4. Mukundan H, Bahadur AK, Kumar A, et al. Glutathine level and its relation to radiation therapy in patients with cancer of uterine cervix. Ind J Exp Biol. 1999; 37: 859-864.

5. Overington JP, Al-Lazikani B, Hopkins AL. How many drug targets are there? Nat Rev Drug Discov. 2006; 5: 993-6.

6. Imming P, Sinning C, Meyer A. Drugs, their targets and the nature and number of drug targets. Nat Rev Drug Discov. 2006; 5: 821-34.

7. Sievert MK, Hajipour AR, Ruoho AE. Specific derivatization of the vesicle monoamine transporter with novel carrier-free radioiodinated reserpine and tetrabenazine photoaffinity labels. Anal Biochem. 2007; 36: 68-78.

8. Mandela P, Chandley M, Xu YY, Zhu MY, Ordway GA. Reserpine-induced reduction in norepinephrine transporter function requires catecholamine storage vesicles. Neurochem Int. 2010; 56: 760-7.

9. Rui Cui, Yunxiao Kang, Li Wang, et al. Testosterone Propionate Exacerbates the Deficits of Nigrostriatal Dopaminergic System and Downregulates Nrf2 Expression in Reserpine-Treated Aged Male Rats. Front. Aging Neurosci. 2017; 9: 172.

10. Metzger RR, Brown JM, Sandoval V, et al. Inhibitory effect of reserpine on dopamine transporter function. Eur. J. Pharmacol. 2002; 456: 39-43.

11. Antkiewicz-Michaluk L, Wąsik A, Możdżeń E, Romańska I, Michaluk J. Antidepressant-like effect of tetrahydroisoquinoline amines in the animal model of depressive disorder induced by repeated administration of a low dose of reserpine: behavioral and neurochemical studies in the rat. Neurotox Res. 2014; 26: 85-98.
12. Salih B, Sipahi T, Dönmez EO. Ancient nigella seeds from Boyali Höyük in northcentral Turkey. J Ethnopharmacol. 2009; 124: 416-20.

13. Ghosheh OA, Houdi AA, Crooks PA. High performance liquid chromatographic analysis of the pharmacologically active quinones and related compounds in the oil of the black seed (Nigella sativa L.). J Pharm Biomed Anal. 1999; 19: 757-62.

14. Kanter M, Coskun O, Uysal H. The antioxidative and antihistaminic effect of Nigella sativa and its major constituent, thymoquinone on ethanol-induced gastricmucosal damage. Arch Toxicol. 2006; 80: 21724.

15. Hassanein KMA, El-Amir Y. Protective effects of thymoquinone and avenanthramides on titanium dioxide nanoparticles induced toxicity in SpragueDawley rats. Pathol Res Pract. 2017; 213: 13-22.

16. Awad AS, Kamel R, Sherief MA. Effect of thymoquinone on hepatorenal dysfunction and alteration of CYP3A1 and spermidine/ spermine $\mathrm{N}-1$ acetyl-transferase gene expression induced by renal ischaemia-reperfusion in rats. J Pharm Pharmacol. 2011; 63: 1037-42.

17. Kanter M, Coskun O, Kalayci M, Buyukbas S, Cagavi F. Neuroprotective effects of Nigella sativa on experimental spinal cord injury in rats. Hum Exp Toxicol. 2006; 25: 127-33.

18. Nili-Ahmadabadi A, Tavakoli F, Hasanzadeh GR, Rahimi H, Sabzevari O. Protective effect of pretreatment with thymoquinone against Aflatoxin B1 induced liver toxicity in mice. Daru. 2011; 19: 282-87.

19. Yaman I, Balikci E. Protective effects of Nigella sativa against gentamicin-induced nephrotoxicity in rats. Exp. Toxicol. Pathol. 2010; 62: 183-90.

20. Lupidi G, Scire A, Camaioni E et al. Thymoquinone, a potential therapeutic agent of Nigella sativa, binds to site I of human serum albumin. Phytomedicine. 2010; 17: 714-20.

21. Kustimur S, Kalkanci A, Akbulut G et al., The effect of vaginal candidiasis on the levels of the oxidative biomarkers in plasma and tissue samples of diabetic rats. Mycopathologia. 2007; 164: 217-24.

22. Miranda KM, Espey MG, Wink DA. A rapid, simple spectrophotometric method for simultaneous detection of nitrate and nitrite. Nitric Oxide. 2001; 5: 62-71.

23. Rui Cui, Yunxiao Kang, Li Wang et al. Testosterone Propionate Exacerbates the Deficits of Nigrostriatal Dopaminergic System and Downregulates Nrf2 
Expression in Reserpine-Treated Aged Male Rats. Front. Aging Neurosci. 2017; 9: 172.

24. Abdel-Majeed S, Mohammad A, Shaima AB, Mohammad R, Shaker A. Mousa. Inhibition property of gren tea extract in relation to reserpine-induced ribosomal strips of rough endoplasmic reticulum (rER) of the rat kidney proximal tubule cells. The journal of Toxicological Sciences. 2009; 34: 637-45.

25. Al-Bloushi S, Safer AM, Afzal M, Shaker A. Mousa. Green tea modulates reserpine toxicity in animal models. The journal of Toxicological Sciences. 2009; 34: 77-87.

26. Kishimoto K, Fukuyado T, Sawamoto O, Kurısu K. Influence of dally subcutaneous administration of reserpine for 4 weeks or 9 weeks before mating on testıs, sperm and male fertılity in rats. The journal of Toxicological Sciences. 1995; 20; 367-74.
27. Dias PLR. Histometric analysis of the effects of reserpine on the interstitial cells of the rat testıs. Br. J. Exp. Path. 1982; 63: 518.

28. Sayeda MM, Hassaneinb KMA, Senosy W. Protective effects of thymoquinone and l-cysteine on cadmiuminduced reproductive toxicity in rats. Toxicology Reports. 2014; 1: 612-20.

29. Mabrouk A, Cheikh HB. Thymoquinone supplementation reverses lead-induced oxidative stres in adult rat testes. Gen. Physiol. Biophys. 2015; 34: 6572 .

30. Hassanein KMA, El-Amir YO. Ameliorative effects of thymoquinone on titanium dioxide nanoparticles induced acute toxicity in rats International Journal of Veterinary Science and Medicine. 2018; 6: 16-21. 